\title{
A Study of the Factors Influencing the Eff- ciency of Different Forms of Nitrogen as Related to Soil Type and Cropping System in the Atlantic Coastal Plain Region. Part I.
}

ARThur Matthias Smith.

A Dissertation Submitted to the Faculty of the Graduate School of the University of Maryland in Partial Fulfilment of the Requirements for the Degree of Doctor of Philosophy.

COLLEGE PARK, MARYLAND

FEBRUARY, 1927

Reprint from Soil Science, Vol. XXIII: No. 2, p. 137-164. February, 1927. 
UMI Number: DP70184

All rights reserved

INFORMATION TO ALL USERS

The quality of this reproduction is dependent upon the quality of the copy submitted.

In the unlikely event that the author did not send a complete manuscript and there are missing pages, these will be noted. Also, if material had to be removed, a note will indicate the deletion.

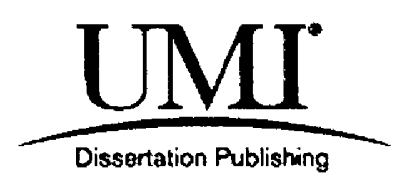

UMI DP70184

Published by ProQuest LLC (2015). Copyright in the Dissertation held by the Author.

Microform Edition @ ProQuest LLC.

All rights reserved. This work is protected against unauthorized copying under Title 17, United States Code



ProQuest LLC.

789 East Eisenhower Parkway

P.O. Box 1346

Ann Arbor, Ml 48106 - 1346 


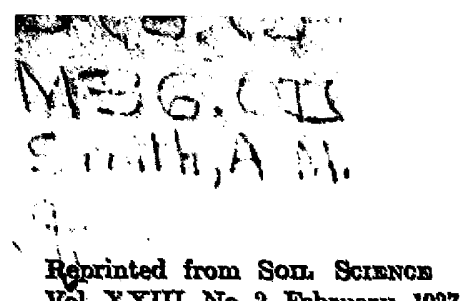

\title{
A STUDY OF THE FACTORS INFLUENCING THE EFFICIENCY OF DIFFERENT FORMS OF NITROGEN AS RELATED TO SOIL TYPE AND CROPPING SYSTEM IN THE ATLANTIC COASTAL PLAIN REGION: PART I ${ }^{1}$
}

\author{
ARTHUR MATTHIAS SMITH + \\ University of Maryland
}

Received for publication April 28, 1926

\section{INTRODUCTION}

The economic utilization of nitrogen fertilizers is one of the outstanding problems of the market gardeners and truck farmers on the sandy soils of the Atlantic Coastal Plain. The Norfolk, Sassafras, Ruston, Keyport, and Elkton soils in particular contain relatively small amounts of nitrogen, and are usually coarse in texture. Since in many areas the subsoi? contains even more sand than the surface soil, these soils are frequently subject to excessive leaching from both winter and summer rains. Especially in the tide-water regions of Maryland and Virginia, where the permanent water-table is close to the surface soil, large amounts of nitrogen are lost annually by leaching.

That the supply of available nitrogen is one of the important problems to farmers in the Atlantic Coastal Plain may be realized from the fact that an application of one ton per acre of a 7-6-5 or a 5-8-5 $\left(\mathrm{NH}_{3}-\mathrm{P}_{2} \mathrm{O}_{5}-\mathrm{K}_{2} \mathrm{O}\right)$ commercial fertilizer is the standard practice for early potatoes in many sections. These fertilizers cost on the average from $\$ 45.00$ to $\$ 52.00$ per ton. This has been estimated by economists of the United States Department of Agriculture (76) to be from 26 to 33 per cent of the total cost of producing this crop. For many other truck crops applications of from 1000 to 1500 pounds of similar fertilizers per acre are made.

Since the severe summer showers and heavy winter rains in this region tend toward the excessive leaching of nitrate nitrogen; the farmers have demanded large proportions of organic nitrogen materials in the mixed fertilizers, with a consequent increase in the basic cost of the same.

In this investigation an attempt is made to study some of the fundamental factors involved in the use of complete commercial fertilizers on these soils, with special reference to to the proportion of the nitrogen derived from inorganic and organic nitrogen fertilizer materials.

1 Summarized Introduction and Historical Review, of a Thesis submitted to the Graduate Faculty of the University of Maryland, June, 1925, in partial fulfilment of the requirements of the degree of Doctor of Philosophy. Part II is a detailed report on closely related fieldplot experiments, and will be published at a later date with subsequent data.

2 The writer takes this opportunity to thank Dr. A. G. McCall, under whose direction this investigation was conducted, for his helpful suggestions, kindly criticisms, for the facilities made available, and for reading the manuscript. Thanks are also extended to Director. $\mathrm{H}$. J. Patterson for his kindly coöperation. 


\section{HistoricaL \\ FACTORS INELUENCING THE RATE OF NITRIFICATION \\ The effect of temperature on nitrification}

The work of numerous investigators has shown that nitrification will take place in soils at all temperatures between $15^{\circ}$ and $40^{\circ} \mathrm{C}$. In particular, that of Jacob $\beta$, Allison and Braham (45), and of Panganiban (63) indicates that the optimum temperature is approximately $35^{\circ} \mathrm{C}$.

The consensus of opinion from the work of Lemmerman and Wichers (50); Fraps (28); Whiting and Schoonover (80); Shonbrunn (70), Blair and Prince (10); Gowda (35); and others, is that seasonal variations in the rate of nitrification are due largely to temperature, moisture, and other seasonal changes in the soil.

\section{Moisture relations}

Harris and Butt (40) found that a soil-moisture content of 23 to 28 per cent was optimum for nitrification. The work of Coleman (24), and of Jacobs, Allison and Braham (45) indicates that for most soils 50 to 60 per cent of the water-holding capacity is the optimum. Sachs and Austin (65), Albrecht (1), The Nebraska Agricultural Experiment Station (62), Munter (59), Carpenter and Bose (19), and Hall (38), all found that tillage practices designed to conserve moisture in field soils during the summer, increased the amount of nitrification.

\section{Loss by leaching}

The work of Garretson (32) and of Geilman (33) shows very little leaching of the ammonia form of nitrogen; most of the nitrogen lost in this manner being nitrate. Blair (10) found no more leaching when nitrate of soda was added to the soil used than when organic ammoniates were added. This brings up the question of soil texture and chemical composition in relation to the influence of sodium. Harrison (41) showed that a fairly heavy soil to a depth of 3 to 4 feet is necessary to prevent excessive leaching. The work of Wilson (81), and of Fraps (28) illustrates the value of crops and manures in conserving soil nitrates.

The previous work indicates that the leaching of soil nitrates is the resultant between the factors of soil texture, soil composition, climate, and the cropping and manuring systems.

\section{The effect of soil reaction}

The wide range of $\mathrm{H}$-ion concentrations in soils in which nitrification is reported to have proceeded vigorously, leads one to believe that other soil factors such as moisture, temperature, buffer substances, i.e. organic matter, colloidal clay and zeolites, and microörganisms as well, may, in many instances, outweigh the influence of either an unfavorable OH- or H-ion concentration. This view is supported by the work of Fred and Graul (30), Garder and Hagum (31), Meek and Lipman (57), Barthel and Bengston (8), Fraps (28), Stevenson (73), Chardon-Placios (20), Blair and Prince (11), Shedd (69), Waksman (79), Munter (60), Murphy (61), Albrecht (3), and Denison (25).

For mineral soils the optimum reaction appears to be at about $\mathrm{pH} 7.0$; although maximum values of $\mathrm{OH}$-ion concentration of 13.0 and minimum values of $\mathrm{pH} 5.4$ have been recorded. The work of Fraps (28), Murphy (61), and many others indicates that liming the soil favors nitrification; an exception being the work of Blair and Prince when using sulfate of ammonia as a fertilizer. Minimum values of $\mathrm{pH} 4.0$ have been observed in peat soils. This is in line. with Waksman's researches and explanation of the influence of various buffering materials.

\section{The influence of salts on nitrification}

The relation of salts to the nitrification process is of importance with respect to the influence of the non-nitrogenous fertilizer salts on the rate of availability of the nitrogen con- 
tained in the fertilizer and also in the soil. Greaves (36) found that in alkali soils many salts increased the rate of nitrification. Erdman (27) found that normal applications of gypsum had no effect. Brown and Gowda (18) found that phosphates and nitrate of soda increased nitrification. The work of Fraps (28) on Texas soils showed phosphates to be more effective than potash in stimulating nitrifying bacteria. R. S. Smith (71) found that potassium sulfate stimulated and potassium chloride decreased the rate of nitrification.

\section{Infuence of the source of the nitrogen on nitrification}

In the work of Jacobs, Allison and Braham (45) light applications of cyanamide were entirely nitrified in 5 days; and applications of 216 pounds per acre were completely transformed to nitrate in 10 days. They also found that small quantities of dicyano-diamide did not delay the nitrification of urea, but did delay the transformation of ammonium sulfate for 210 days. Littauer (54) found that urea was nitrified best in a loam soil; and, although drouth retarded the rate, increases in moisture above the average water capacity produced no essential changes in the rate of change to nitrate.

It is evident from the literature that the presence or absence of certain impurities in urea, as determined by the process of manufacture, largely determines the rate of nitrification.

Brenchley and Richards (16) found that all the nitrogen from finely divided dried blood was nitrified after 15 weeks. In the same time 26 per cent of that in slate-bed sewage sludge and 66 per cent of that in activated sludge has been changed to nitrate.

\section{PLANTS AS INDICATORS OF THE AVAILABILITY OF NITROGEN FROM VARIOUS}

\section{MATERIALS}

So much experimental work has been published on various crops as indicators of nitrogen availability, that it is possible to cite only a few investigations bearing directly on some phases of the present problem, for example: the work of Schneidewind, Meyer and Munter (68); Hasselhof, Liehr and Fluhrer (42); Kuyper (48); Chevalier (21); Allison, Braham and McMurtey (4); Prescott (64); Allison, Vliet, Skinner, and Reid (5); Brenchley and Richards (16); Brown (17); Lemmerman and Eckl (49); Truffaut and Bezssonoff (74); Woods (83); Lipman and Blair (52); and Martin (56).

The consensus of opinion seems to be that crop response to different nitrogenous materials depends so largely on soil texture and composition, climatic factors, length of growing season and the root system of the crop, that no one material or type, of material is best adapted to all, or even to a large proportion of soils and crops. It has been largely a problem of determining the effects of these various influences on each nitrogen fertilizer, and thus learning its adaptability for any particular soil and crop combination.

The general conclusion seems to be that the water-soluble forms of nitrogen are best adapted to heavy soils and to short or cold growing seasons. For sandy soils, long growing seasons, and high soil temperatures, the soluble and insoluble organic nitrogen materials and the ammonia salts seem better adapted than the nitrate forms.

\section{NITRIFICATION AS A MEASURE OF THE AVAILABILITY OF NITROGEN FOR PLANT GROWTH}

According to the work of Bonazzi (13), and from a consideration of the processes for the synthetic production of ammonia and nitrates, the oxidation of ammonia in soils is accomplished by the catalytic activity of iron as part of a biological intracellular mechanism, through which the inert oxygen of the air is activated. Miyake and Soma (58) have shown that the process of nitrification as a whole resembles an autocatalytic mono-molecular bio- 
chemical reaction; and that the increase of nitrates in soils is in accord with the formula for this type of reaction.

Hasselhof (42); Robinson, Winter, and Miller (65); and others, have shown that although the neutral and alkaline permanganate methods shed some light on the availability of insoluble, but easily hydrolyzable, organic nitrogenous compounds, they do not yield true values when compared with plant-culture experiments. The time consumed and the tedious processes involved make bacteriological and nutritional methods impractical for routine use in control laboratories. However, these latter methods are of real worth in establishng true values for the more rapid chemical methods in present use, or those to be devised in the future.

The work of Lipman and Burgess (51), Bizzell (9), Fraps (29)_Waksman (78), and others, seems to show that nitrification tests under standard conditions are the best biological method for determining the availability of nitrogen in fertilizer materials; unless crop tests can be made under the soil and climatic conditions existing in the field where these materials are to be used. The results obtained by Lipman and Burgess (51) and by Waksman (78) in comparing ammonification and nitrification tests with crop growth experiments, seem to indicate that ammonification tests fail to yield real or consistent values over a wide range of conditions, such as exist in various field soils.

Although the writer is fully conversant with the work recently brought into prominence concerning the availability of the ammonia form of nitrogen to economic crop plants, he is inclined to agree with the findings of these investigators cited above. Although certain plants whose ecological habitat is found in wet, poorly drained, or very acid soils may be shown to take up appreciable quantities of nitrogen in the form of ammonia; the bulk of the evidence from practical farm experience, field plot experiments, pot culture studies, and bacteriological research shows that of the simple transformation products of organic nitrogen, nitrate is the only stable form in the soil; and that the proportion of nitrate to ammonia nitrogen found in most well drained soils proves conclusively that plants do absorb greater quantities of the nitrate form than of the ammonia form of nitrogen. For these reasons nitrification tests were adopted as the criterion of nitrogen availability in the present investigation.

\section{EXPERIMENTAL}

\section{A COMPARISON OF VARIOUS NITROGENOUS FERTILIZER MATERIALS WITH RESPECT TO THE RATE OF NITRIFICATION AND THE LEACHING OF NITRATES FROM NORFOLK SANDY LOAM SOIL}

The surface soil used in these experiments was secured from the experimental field at Snow Hill, Maryland. The data from preliminary mechanical and chemical analyses are given in table 1.

Sulfate of ammonia, urea, dried ground fish, high-grade packing-house tankage, and activated sewage sludge were compared with respect to their rate of nitrification in this soil. The urea was of the usual commercial grade now being sold in this country by the Badische Anilin und Soda Fabrik. The sulfate of ammonia, fish, and tankage were the usual commercial materials. The activated sewage sludge was obtained from Milwaukee, Wisconsin, the material having been produced by the method described by Kadish (46). Commercial nitrate of soda was used in the leaching experiments, and as a control on the nitrate absorption of the soil in the rate of nitrification studies.

In order to obtain an equitable basis for comparison, the organic materials were ground to approximately equal fineness, and to a degree possible under commercial conditions. Sieve tests were then made and the total nitrogen was determined, the results are shown in table 2. 


\section{Series $I$. The infuence of soil moisture on the rate of nitrification}

Each of the nitrogenous materials listed in table 2 was used in turn as the sole source of nitrogen in a complete fertilizer containing 7 per cent ammonia, 6 per cent phosphoric acid, and 5 per cent potash. In all cases the phosphorus and potassium were derived from 16 per cent acid phosphate and 50 per cent sulfate of potash, respectively. Of this fertilizer, $4 \mathrm{gm}$. portions containing

TABLE 1

Mechanical analysis determinations, Norfolk Sandy Loam

\begin{tabular}{|c|c|}
\hline Mechanical analysis:* & \\
\hline Fine gravel and coarse sand $\ldots \ldots \ldots \ldots \ldots \ldots \ldots \ldots \ldots$ per cent & 16.0 \\
\hline 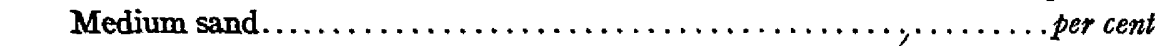 & 31.8 \\
\hline Fine sand $\ldots \ldots \ldots \ldots \ldots \ldots \ldots \ldots \ldots \ldots \ldots \ldots \ldots \ldots$ per cent & 36.4 \\
\hline Very fine sand........................... cent & 4.2 \\
\hline 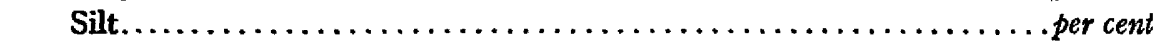 & 9.0 \\
\hline 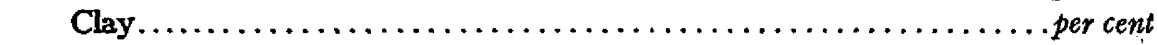 & 2.1 \\
\hline Water-holding capacity..... & 27.1 \\
\hline 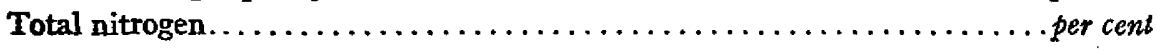 & 0.041 \\
\hline$\ldots$ pF & 6.4 \\
\hline
\end{tabular}

* Method of Bureau of Soils, U. S. Dept. Agr. (15).

TABLE 2

Analyses of nitrogenous materials used

\begin{tabular}{|c|c|c|c|c|c|c|c|}
\hline \multirow[b]{2}{*}{ MATERUIS } & \multirow[b]{2}{*}{ NITROGEN } & \multicolumn{6}{|c|}{ MGECHANICAL ANALYSTS } \\
\hline & & $\begin{array}{c}\text { Coarser } \\
\text { than } \\
20 \\
\text { mesh }\end{array}$ & $\begin{array}{l}20-40 \\
\text { mesh }\end{array}$ & $\begin{array}{l}40-60 \\
\text { mesh }\end{array}$ & $\begin{array}{l}60-80 \\
\text { mesh }\end{array}$ & $\begin{array}{c}80-100 \\
\text { mesh }\end{array}$ & $\begin{array}{c}\text { Finer } \\
\text { than } \\
100 \\
\text { mesh }\end{array}$ \\
\hline & per cent & per cent & percent & percent & per cent & per cent & per cent \\
\hline Dried ground fish. & 9.6 & 0.2 & 4.8 & 29.8 & 19.0 & 8.2 & 37.4 \\
\hline Packing house tankage.. & 10.3 & 0.1 & 1.4 & 24.0 & 17.7 & 10.2 & 46.6 \\
\hline Sewage.............. & 5.1 & $\ldots$ & 2.0 & 37.2 & 16.9 & 8.4 & 35.5 \\
\hline Urea................... & 45.3 & $\ldots$ & $\ldots$ & $\ldots$ & $\ldots$ & $\ldots$ & $\ldots$ \\
\hline Sulfate of ammonia......... & 25.2 & $\ldots$ & $\ldots$ & $\ldots$ & $\ldots$ & $\ldots$ & $\ldots$ \\
\hline Nitrate of soda........ & 14.9 & $\ldots$ & $\ldots$ & $\ldots$ & $\ldots$ & $\ldots$ & $\ldots$ \\
\hline
\end{tabular}

$230.4 \mathrm{mgm}$. of nitrogen each, were added to $4 \mathrm{kgm}$. of sifted air-dry soil contained in 1-gallon glazed pots. These additions correspond to a field application of 2000 pounds of fertilizer per acre.

The rate of nitrification of sulfate of ammonia, urea, fish, and tankage was compared at soil-moisture contents of $10,20,30,40,50,60$, and 70 per cent of the total water-holding capacity of the soil as determined by the Hilgard method (43-a). At the lowest moisture content, $108 \mathrm{gm}$. of water was added 
TABLE 3

The effect of soil-moisture on the rate of nitrification

\begin{tabular}{|c|c|c|c|c|c|c|c|c|c|c|}
\hline \multirow{3}{*}{ MOISTURE CONTENT } & \multirow{3}{*}{$\begin{array}{c}\text { POT } \\
\text { NUMBER }\end{array}$} & \multirow{3}{*}{ SOURCE OF NITROGEN } & \multicolumn{8}{|c|}{ NITRATE-NITROGEN IN AIR-DRY SOII } \\
\hline & & & $\underset{17}{\text { December }}$ & $\begin{array}{c}\text { December } \\
31\end{array}$ & January 14 & January 28 & $\begin{array}{c}\text { February } \\
11\end{array}$ & $\underset{25}{\text { February }}$ & March 11 & March 25 \\
\hline & & & 0 days & 14 days & 28 days & 42 days & 56 days & 70 days & 84 days & 98 days \\
\hline \multirow{5}{*}{$\begin{array}{l}10 \text { per cent of } \\
\text { water-holding } \\
\text { capacity }\end{array}$} & & & $p . p . m$. & $p . p . m$. & p.p.m. & $p \cdot p . m$. & $p \cdot p \cdot m$. & p.p.m. & p.p.m. & p.p.m. \\
\hline & 1 & Sulfate of ammonia & 1.9 & 5.5 & 6.9 & 6.8 & 6.7 & 7.5 & 5.7 & 8.2 \\
\hline & 2 & Urea & 0.6 & 5.6 & 7.1 & 6.5 & 7.1 & 7.5 & 8.2 & 11.1 \\
\hline & 3 & Dried ground fish & 1.0 & 6.0 & 6.9 & 7.2 & 7.4 & 9.2 & 6.5 & 9.8 \\
\hline & 4 & Tankage & 2.4 & 5.8 & 7.1 & 6.1 & 5.7 & 7.0 & 5.1 & 7.1 \\
\hline \multirow{4}{*}{$\begin{array}{l}20 \text { per cent of } \\
\text { water-holding } \\
\text { capacity }\end{array}$} & 5 & Sulfate of ammonia & 1.9 & 2.6 & 7.2 & 12.4 & 21.4 & 30.1 & 22.7 & 41.7 \\
\hline & 6 & Urea & 0.6 & 4.7 & 13.7 & 15.2 & 22.4 & 29.3 & 29.3 & 44.9 \\
\hline & 7 & Dried ground fish & 1.0 & 5.4 & 11.1 & 14.7 & 20.4 & 19.6 & 26.8 & 27.1 \\
\hline & 8 & Tankage & 2.4 & 5.1 & 11.1 & 14.9 & 27.6 & 21.2 & 28.3 & 31.3 \\
\hline \multirow{4}{*}{$\begin{array}{l}30 \text { per cent of } \\
\text { water-holding } \\
\text { capacity }\end{array}$} & 9 & Sulfate of ammonia & 1.9 & 3.4 & 12.7 & 14.2 & 22.2 & 34.4 & 34.4 & 57.7 \\
\hline & 10 & Urea & 0.6 & 4.3 & 16.4 & 27.8 & 32.2 & 37.9 & 43.4 & 52.1 \\
\hline & 11 & Dried ground fish & 1.0 & 2.0 & 14.8 & 21.7 & 28.1 & 53.6 & 37.5 & 43.6 \\
\hline & 12 & Tankage & 2.4 & 4.6 & 16.2 & 19.9 & 23.7 & 39.9 & 29.4 & 45.7 \\
\hline \multirow{4}{*}{$\begin{array}{l}40 \text { per cent of } \\
\text { water-holding } \\
\text { capacity }\end{array}$} & 13 & Sulfate of ammonia & 1.9 & 2.9 & 14.8 & 25.9 & 36.8 & 41.7 & 40.1 & 37.5 \\
\hline & 14 & Urea & 0.6 & 8.8 & 34.5 & 32.0 & 36.8 & 54.0 & 36.2 & 30.0 \\
\hline & 15 & Dried ground fish & 1.0 & 4.5 & 13.2 & 24.4 & 37.5 & 53.6 & 34.3 & 47.8 \\
\hline & 16 & Tankage & 2.4 & 5.6 & 18.5 & 27.4 & 38.3 & 50.0 & 31.3 & 49.3 \\
\hline
\end{tabular}




\begin{tabular}{|c|c|c|c|c|c|c|c|c|c|c|}
\hline \multirow{7}{*}{$\begin{array}{l}50 \text { per cent of } \\
\text { water-holding } \\
\text { capacity }\end{array}$} & 17 & Sulfate of ammonia & 1.9 & 6.1 & 17.8 & 30.5 & 49.3 & 58.6 & 45.7 & 73.5 \\
\hline & 18 & Urea & 0.6 & 6.5 & 19.8 & 35.4 & 59.5 & 67.0 & 21.3 & 51.7 \\
\hline & 19 & Dried ground fish & 1.0 & 4.0 & 15.8 & 25.5 & 47.9 & 47.5 & 35.4 & 37.5 \\
\hline & 20 & Tankage & 2.4 & 6.8 & 18.7 & 28.2 & 46.6 & 52.8 & 28.9 & 22.7 \\
\hline & 21 & Nitrate soda & 65.2 & 20.3 & 73.5 & 69.5 & 80.7 & 85.2 & 35.7 & 60.0 \\
\hline & 22 & Sewage & 1.7 & 5.2 & 17.6 & 25.0 & 28.6 & 33.3 & 21.3 & 30.6 \\
\hline & 23 & $0-6-5$ & 1.9 & 0.3 & 13.7 & 15.8 & 14.7 & 19.9 & 12.3 & 16.0 \\
\hline \multirow{4}{*}{$\begin{array}{l}60 \text { per cent of } \\
\text { water-holding } \\
\text { capacity }\end{array}$} & 24 & Sulfate of ammonia & 1.9 & 5.8 & 18.7 & 37.9 & 48.7 & 65.8 & 53.6 & 51.7 \\
\hline & 25 & Urea & 0.6 & 7.4 & 31.1 & 66.4 & 62.5 & 76.5 & 60.0 & 62.5 \\
\hline & 26 & Dried ground fish & 1.0 & 7.7 & 17.5 & 41.2 & 41.4 & 56.8 & 29.3 & 44.1 \\
\hline & 27 & Tankage & 2.4 & 7.1 & 20.9 & 40.1 & 39.5 & 50.3 & 21.1 & 40.5 \\
\hline \multirow{4}{*}{$\begin{array}{l}70 \text { per cent of } \\
\text { water-holding } \\
\text { capacity }\end{array}$} & 28 & Sulfate of ammonia & 1.9 & 7.8 & 20.0 & 42.9 & 37.5 & 54.0 & 45.2 & 32.1 \\
\hline & 29 & Urea & 0.6 & 6.8 & 29.9 & 67.0 & 49.3 & 67.0 & 69.5 & 69.5 \\
\hline & 30 & Dried ground fish & 1.0 & 5.1 & 17.3 & 42.9 & 41.4 & 44.1 & 48.4 & 27.3 \\
\hline & 31 & Tankage & 2.4 & 7.3 & 20.6 & 40.3 & 37.1 & 41.9 & 43.4 & 28.2 \\
\hline \multicolumn{3}{|c|}{ Mean air temperature. } & & $\begin{array}{l}14.0 \\
57.1\end{array}$ & $\begin{array}{l}15.1 \\
59.7\end{array}$ & $\begin{array}{l}16.1 \\
61.8\end{array}$ & $\begin{array}{l}18.0 \\
64.1\end{array}$ & $\begin{array}{l}17.1 \\
63.3\end{array}$ & $\begin{array}{l}18.1 \\
64.8\end{array}$ & $\begin{array}{l}18.0 \\
63.9\end{array}$ \\
\hline
\end{tabular}


to $4000 \mathrm{gm}$. of soil, while at the highest, $761 \mathrm{gm}$. of water was added. The experiment was conducted in the greenhouse for a period of 98 days from December 17 to March 25, during which time the pots were neither covered nor shaded. The pots were weighed twice each week, and distilled water was added to replace the loss by evaporation. After each sampling the soils were cultivated to a depth of $\frac{1}{2}$ inch. -

At 50 per cent of the water-holding capacity three additional fertilizer treatments were employed. In one of these, activated sludge was used as the nitrogenous material. Another, in which nitrate of soda was used, served as a control pot for measuring nitrate absorption by the soil and the utilization of nitrates by soil organisms. The third, to which no nitrogen was added, served as a control to measure the rate of nitrification of the original soil nitrogen.

In order to obtain representative samples, borings from the top to the bottom of each pot were made at 14-day intervals. Seventy-gram samples of the moist soil were dried in the oven at $50^{\circ} \mathrm{C}$. for 15 hours, and 50 -gram portions

TABLE 4

Time-periods required for the nitrate nitrogen to equal the total nitrogen applied in the fertilizer

\begin{tabular}{|c|c|c|c|c|c|c|c|}
\hline \multirow{2}{*}{ MATERIALS } & \multicolumn{7}{|c|}{ SOIL-MOLSTURE AS PER CENT WATER-HOLDINC CAPACITY } \\
\hline & $\begin{array}{c}10 \mathrm{per} \\
\text { cent }\end{array}$ & $\begin{array}{c}20 \text { per } \\
\text { cent }\end{array}$ & $\begin{array}{c}30 \text { per } \\
\text { cent }\end{array}$ & $\begin{array}{c}40 \text { per } \\
\text { cent }\end{array}$ & $\begin{array}{c}50 \text { per } \\
\text { cent }\end{array}$ & $\begin{array}{l}60 \text { per } \\
\text { cent }\end{array}$ & $\begin{array}{c}70 \text { per } \\
\text { cent }\end{array}$ \\
\hline & days & days & days & days & days & days & days \\
\hline Sulfate of ammonia. & . & $\ldots$ & 98 & $\ldots$ & 70 & 70 & $70^{*}$ \\
\hline Urea............. & $\ldots$ & $\ldots$ & $98^{*}$ & $70^{*}$ & 56 & 42 & 42 \\
\hline Dried ground fish. . . . . . & $\ldots$ & $\ldots$ & $70^{*}$ & $70^{*}$ & $\ldots$ & 70 & $\ldots$ \\
\hline Packing house tankage..... & $\cdots$ & $\ldots$ & $\ldots$ & $70^{*}$ & $70^{*}$ & $70^{*}$ & $\ldots$ \\
\hline
\end{tabular}

* Amounts slightly less than 57.6 p.p.m.

of the dried soil were then extracted with $250 \mathrm{cc}$. of distilled water. Nitrates were determined throughout by the phenol-disulfonic acid method as modified by Harper (39).

The results of the nitrate determinations for each 14-day period are shown in table 3 , in which the nitrate-nitrogen is expressed as parts per million of airdry soil.

An inspection of table 3 shows that, in general, for the first 42-day period the rate of nitrification increased in direct proportion to the increase in soil moisture. For the 42 to 98 -day period there was a direct increase in nitrification with increasing soil moisture up to 50 per cent of the water-holding capacity of the soil, except in the case of urea, which yielded a high nitrate content at both 60 and 70 per cent of the water-holding capacity.

At the lowest moisture content very little nitrification took place from any of the materials added. At the 20 per cent level and, in fact, at all of the higher moisture contents, urea and sulfate of ammonia nitrified more rapidly and gave higher nitrate accumulations than either fish or tankage. 
Considerable variation in the nitrate accumulation for all of the materials may be noticed at the higher soil moisture contents after the 56-day period. This periodicity during short intervals has been noted by numerous investigators. Löhnis in particular (54) has observed similar fluctuations due to biological factors, such as the utilization of nitrates by microörganisms other than the nitrate bacteria. In the present experiment the fluctuations cannot be explained satisfactorily on the basis of differences in soil moisture, temperature, or $\mathrm{H}$-ion concentration, and accordingly are probably due to nutritional differences caused by the various rates of decomposition of the soil organic matter as influenced by the decomposition products and the nitrification of the materials added.

The theoretically possible concentration of nitrate nitrogen as calculated from the total nitrogen contained in the soil and fertilizer, is 467.6 p.p.m., of which 57.6 p.p.m. was added in the fertilizer. It is interesting to observe for the various soil-moisture contents the time required with the different materials for the nitrate-nitrogen to equal the nitrogen added in the fertilizer. These observations are presented in table 4.

From this summary it may be noted that in this soil, under the conditions of the experiment, the optimum soil-moisture content for the nitrification of these four materials lies between 50 and 60 per cent of the water-holding capacity. It will also be noted that a greatest total nitrate accumulation occurred at somewhat higher moisture contents for sulfate of ammonia and for urea than for either fish or tankage. The rate of nitrification in this soil at moisture contents of 30 per cent of the water-holding capacity or less is exceedingly slow. Of the four materials, urea nitrified most readily, and, with the exception of nitrate of soda and of sulfate of ammonia at certain moisture contents, gave the highest accumulation of nitrates.

It is not to be supposed that all of the nitrate-nitrogen was derived from the fertilizer materials. The work of R. S. Smith (71), Gowda (35), and others has shown that both phosphates and potassium salts stimulate nitrification of the original nitrogen contained in the soil. Table 3 shows numerous instances of nitrate accumulation greater than the amount of nitrogen supplied in the fertilizer. It is interesting to note that pot 27 , which received nitrate of soda, showed not only the greatest accumulation of nitrate nitrogen, but also the largest excess over that supplied in the fertilizer. This shows a direct stimulation of nitrification by this material. The fluctuation in nitrate nitrogen in this pot at the different time intervals would indicate that nitrate of soda also stimulated the growth and activity of the other soil organisms.

After the first 28 days at 50 per cent of the water-holding-capacity of the soil, the nitrification of sewage sludge took place very slowly. After the first 14 days, the pot receiving phosphate and potash only had a much lower nitrate content than any of those receiving nitrogenous fertilizers.

The $\mathrm{H}$-ion concentration of the soil as determined colorimetrically at the beginning of the experiment was $\mathrm{pH}$ 6.4. There was no noticeable difference 
TABLE 5

The effect of soil temperahure on the rate of nitrification

\begin{tabular}{|c|c|c|c|c|c|c|c|c|c|c|}
\hline & \multirow{3}{*}{$\begin{array}{c}\text { POT } \\
\text { NOMABER }\end{array}$} & \multirow{3}{*}{ SOURCE OP NITROGEN } & \multicolumn{8}{|c|}{ NITRATE-NITROGEN IN ATR-DRY SOIL } \\
\hline & & & $\underset{17}{\text { December }_{17}}$ & $\underset{31}{\text { December }}$ & January 14 & January 28 & $\begin{array}{l}\text { February } \\
11\end{array}$ & $\underset{25}{\text { February }}$ & March 11 & March 25 \\
\hline & & & 0 days & 14 days & 28 days & 42 days & 56 days & 70 days & 84 days & 98 days \\
\hline \multirow{7}{*}{ Cold room } & & & $p \cdot p \cdot m$ & $p . p . m$. & p.p.m. & $p \cdot p \cdot m$. & $p \cdot p \cdot m$. & p.p.m. & p.p.m. & p.p.m. \\
\hline & 44 & Sulfate of ammonia & 1.9 & 3.4 & 11.2 & 9.7 & 10.4 & 15.8 & 39.7 & 49.0 \\
\hline & 45 & Urea & 0.6 & 3.4 & 9.9 & 10.3 & 10.5 & 18.8 & 48.4 & 63.0 \\
\hline & 46 & Dried ground fish & 1.0 & 1.9 & 13.2 & 8.8 & 10.5 & 16.7 & 41.0 & 45.7 \\
\hline & 47 & Tankage & 2.4 & 2.4 & 10.7 & 10.3 & 11.8 & 19.2 & 41.0 & 48.7 \\
\hline & 48 & Sewage & 1.7 & 2.5 & 9.5 & 9.7 & 11.0 & 18.3 & 31.9 & 28.9 \\
\hline & 49 & $0-6-5$ check & 1.9 & 3.5 & 11.2 & 10.8 & 12.4 & 13.6 & 17.1 & 14.4 \\
\hline \multirow{6}{*}{$\begin{array}{c}\text { Shaded } \\
\text { green } \\
\text { house }\end{array}$} & 32 & Sulfate of ammonia & 1.9 & 3.9 & 14.1 & 36.8 & 37.9 & 56.4 & 44.4 & 75.0 \\
\hline & 33 & Urea & 0.6 & 5.1 & 25.8 & 50.0 & 50.3 & 62.5 & 62.0 & 73.5 \\
\hline & 34 & Dried ground fish & 1.0 & 5.5 & 16.9 & 39.9 & 36.4 & 51.4 & 48.1 & 61.5 \\
\hline & 35 & Tankage & 2.4 & 5.6 & 20.4 & 37.1 & 37.9 & 58.6 & 44.9 & 79.0 \\
\hline & 36 & Sewage & 1.7 & 7.4 & 20.8 & 30.5 & 31.3 & 32.6 & 35.1 & 34.9 \\
\hline & 37 & $0-6-5$ check & 1.9 & 2.8 & 14.4 & 18.5 & 14.9 & 24.8 & 18.3 & 22.1 \\
\hline \multirow{7}{*}{$\begin{array}{l}\text { Not shaded } \\
\text { green } \\
\text { house }\end{array}$} & 17 & Sulfate of ammonia & 1.9 & 6.1 & 17.8 & 30.5 & 49.3 & 58.6 & 45.7 & 73.5 \\
\hline & 18 & Urea & 0.6 & 6.5 & 19.8 & 35.4 & 59.5 & 67.0 & 21.3 & 51.7 \\
\hline & 19 & Dried ground fish & $\cdot 1.0$ & 4.0 & 15.8 & 25.5 & 47.9 & 47.5 & 35.4 & 37.5 \\
\hline & 20 & Tankage & 2.4 & 6.8 & 18.7 & 28.2 & 46.6 & 52.8 & 28.9 & 22.7 \\
\hline & 21 & Nitrate soda & 65.2 & 20.3 & 73.5 & 69.5 & 80.7 & 35.2 & 35.7 & 60.0 \\
\hline & 22 & Sewage & 1.7 & 5.2 & 17.6 & 25.0 & 28.6 & 33.3 & 21.3 & 30.6 \\
\hline & 23 & $0-6-5$ check & 1.9 & 6.3 & 13.7 & 15.8 & 14.7 & 19.9 & 12.3 & 16.0 \\
\hline
\end{tabular}




\begin{tabular}{|c|c|c|c|c|c|c|c|c|c|c|}
\hline $\begin{array}{l}\text { Warm rose } \\
\text { house }\end{array}$ & $\begin{array}{l}38 \\
39 \\
40 \\
41 \\
42 \\
43\end{array}$ & $\begin{array}{l}\text { Sulfate of ammonin } \\
\text { Urea } \\
\text { Dried ground fish } \\
\text { Tankage } \\
\text { Sewage } \\
0-6-5 \text { check }\end{array}$ & $\begin{array}{l}1.9 \\
0.6 \\
1.0 \\
2.4 \\
1.7 \\
1.9\end{array}$ & $\begin{array}{l}4.7 \\
5.9 \\
3.2 \\
6.8 \\
6.7 \\
6.3\end{array}$ & $\begin{array}{l}19.3 \\
29.8 \\
23.3 \\
29.2 \\
22.3 \\
11.7\end{array}$ & $\begin{array}{l}52.5 \\
75.0 \\
48.1 \\
51.7 \\
41.7 \\
18.6\end{array}$ & $\begin{array}{l}54.8 \\
70.8 \\
50.7 \\
50.7 \\
35.7 \\
23.8\end{array}$ & $\begin{array}{l}52.5 \\
75.0 \\
50.0 \\
49.3 \\
41.0 \\
20.8\end{array}$ & $\begin{array}{l}70.1 \\
81.5 \\
65.2 \\
57.7 \\
30.5 \\
12.5\end{array}$ & $\begin{array}{r}117.2 \\
61.0 \\
79.8 \\
90.4 \\
60.0 \\
26.1\end{array}$ \\
\hline \multicolumn{3}{|c|}{ Mean air temperature (main greenhouse) } & $\left\{\begin{array}{l}{ }^{\circ} \mathrm{C} . \\
{ }^{\circ} \mathrm{F} .\end{array}\right.$ & $\begin{array}{l}14.0 \\
57.1\end{array}$ & $\begin{array}{l}15.1 \\
59.7\end{array}$ & $\begin{array}{l}16.1 \\
61.8\end{array}$ & $\begin{array}{l}18.0 \\
64.1\end{array}$ & $\begin{array}{l}17.1 \\
63.3\end{array}$ & $\begin{array}{l}18.1 \\
64.8\end{array}$ & $\begin{array}{l}18.0 \\
63.9\end{array}$ \\
\hline
\end{tabular}


in the $\mathrm{H}$-ion concentration after 98 days with respect to the various moisture contents. In the soil receiving the fertilizer containing sulfate of ammonia, the initial $\mathrm{H}$-ion concentration was $\mathrm{pH}$ 6.0. After 98 days the average $\mathrm{pH}$ values for the soils receiving the various sources of nitrogen were: sulfate of ammonia, 5.6; urea, 5.7; fish and tankage, 5.9. As might have been predicted from the mechanical analysis, given in table $I$, the buffer action of this soil is relatively low. The temperature relations will be discussed in connection with the next series of experiments.

\section{Series II. The influence of soil temperature on the rate of nitrification}

The duration, periods of sampling, containers, weight and type of soil employed, and the analysis and rate of application of the fertilizer were the same in Series II as in the preceding series.

The following materials were used as the sole source of nitrogen in the 7-6-5 complete fertilizer: sulfate of ammonia, urea, dried ground fish, packing-house tankage, and activated sewage sludge. A check treatment of phosphate and potash only was included in each group. To each pot, water was added to 50 per cent of the water-holding capacity of the soil, and the loss by evaporation was replaced twice each week.

Four groups of 6 pots each, treated as indicated above, were kept for 98 days at different temperatures. The first group, pots 44 to 49 as shown in table 5, was kept in a cold room, which received daylight through several windows. The second group, pots 32 to 37 , was kept on a shelf under a stonetop table in the main greenhouse and was protected at all times from the warming effect of direct sunlight. The third group, pots 17 to 23, was placed in the main greenhouse and exposed to sunlight. This group is included in Series $I$ as the 50 per cent water-holding capacity treatment. The fourth group, pots 38 to 43 , was placed in a rose greenhouse where the temperature was maintained at a higher and more uniform temperature than in the house first mentioned.

No attempt was made to control the temperature of the soils, but frequent thermometer readings showed the following temperature conditions. The soil-temperature in the cold room ranged during the first 56 days from $3^{\circ}$ to $12^{\circ} \mathrm{C}$, and for the last 42 days from $12^{\circ}$ to $17^{\circ} \mathrm{C}$. The mean temperature for each bi-weekly period in the main greenhouse as recorded by a thermograph, is given at the foot of tables 3 and 5 . The weekly average of the maximum air temperatures ranged from $17.5^{\circ}$ to $27^{\circ} \mathrm{C}$., and the weekly average minimum from $7^{\circ}$ to $13^{\circ} \mathrm{C}$, giving an average diurnal change of $10.5^{\circ}$ to $13^{\circ} \mathrm{C}$. The soil temperatures, of course, did not undergo either of these extreme fluctuations, having at most times a lag of 3 to $5^{\circ} \mathrm{C}$. for rising and falling temperatures. The soil in pots 32 to 37 shaded by the stone-top table was at all times during sunny days from $2^{\circ}$ to $3^{\circ} \mathrm{C}$. cooler than pots 17 to 23 placed on top of the wooden table. The soils in pots 38 to 43 in the warmer greenhouse averaged at all times from $3^{\circ}$ to $5^{\circ} \mathrm{C}$. warmer than pots 17 to 23 in the main 
unshaded greenhouse. During periods of exceedingly cold weather these soils frequently had a temperature $8^{\circ} \mathrm{C}$. higher than those of the main greenhouse.

The object in comparing the rates of nitrification of these materials at different temperature levels was to ascertain, if possible, their adaptation for both early and midseason crops.

The results of the nitrate determinations at successive 14-day intervals are shown in table 5 .

It may be seen from the data that in the pots placed in the cold room, the rate of nitrification during the first 70 days was slow for all of the nitrogenous materials employed, being at the most only 50 per cent more than for the soil alone. There was, however, a gradual nitrate accumulation at this low temperature level. During the last 28 days, as the temperature increased with the rising outdoor temperatures, there was an appreciable nitrate accumulation in all cases, equaling with some of the materials, the amounts shown in the main greenhouse where higher temperatures prevailed. The rapidity of nitrification at this low temperature level was in the following order: urea, then tankage, sulfate of ammonia, and fish closely grouped, activated sewage sludge, and no applied nitrogen. These results would indicate that urea might have a slight advantage over the other materials as a source of nitrogen for early spring or winter crops.

A comparison of the data for the shaded and unshaded soils in the main greenhouse shows considerable variation in the effect of the shading. Although in general the slightly higher temperatures resulting from the exposure to sunlight induced a slightly more rapid nitrification at the start, and with the exception of the activated sewage sludge, yielded a higher nitrate accumulation at the 56-day period, the influence of the slight temperature difference is not consistent. Of two possible explanations one is, that the greater loss of water by evaporation from the group exposed to sunlight may have offset the advantage of the slightly higher temperature attained. In Series $I$ it is shown that $\mathbf{5 0}$ per cent of the moisture holding capacity approaches the lower limit of the optimum water content for nitrification in this soil. Accordingly, the more rapid evaporation would not provide more favorable moisture relations or stimulate nitrification through increased soil aeration.

In view of the data for Series I, however, in which there was a fluctuation in the nitrate accumulation from these materials at all soil-moisture levels of 30 per cent of the water-holding capacity and higher, and under the same temperature range as for numbers 17 to 23 , the explanation does not seem to lie in a difference in moisture content. It will be observed that the nitrate accumulations in the soils exposed to sunlight showed more extreme fluctuations than those in the shaded soils, although the variations in the two groups agree in general with respect to the time periods of sampling. From the data it appears that the slightly higher temperatures attained during sunny days in the group exposed to sunlight, stimulated the growth and activity of the entire microbiological flora of this soil, to the extent of utilizing a larger portion 
of the accumulated nitrates, than was the case in the shaded soils. This hypothesis is strengthened by the fact that for practically every treatment in the shaded, as well as in the unshaded soils, there was an actual decrease in nitrate accumulation at the end of the bi-weekly periods during which there was an increase in the mean temperature. Thus there was very little increase in nitrate accumulation in the shaded soils from the 42- to the 56-day period during which time there was an increase in mean temperature of $1.9^{\circ} \mathrm{C}$. Although the soils exposed to sunlight showed a consistent accumulation of nitrates from all the materials under comparison for the first 70 days, during the next 14-day period there was a decided decrease in nitrates in both the shaded and unshaded soils. At the same time the mean temperature increased $1.0^{\circ} \mathrm{C}$. During the final 14-day period immediately following, there was again a marked increase in nitrate accumulation in both shaded and unshaded soils in nearly every case, while the mean temperature remained practically constant.

That this fluctuation in nitrate accumulation is due to the utilization of nitrates by soil microörganisms, as stimulated by a slightly increased mean temperature, is further indicated by referring in table 3 to the analyses at the 84-day period. The nitrate accumulations from urea, fish, and tankage at soil moisture levels of 30 and 40 per cent of the moisture-holding capacity equaled or exceeded the accumulations from the same materials during the same time in the soils moistened to 50 per cent, and, for some materials, to 60 per cent of the moisture-holding capacity. This would indicate that the fluctuations in the amounts of nitrate accumulations were not due to the more rapid evaporation of water at the slightly higher mean temperature levels. It may also be observed from table 3 that increasing mean temperatures did not offset the unfavorable conditions due to supra-optimum moisture relations in the group of soils moistened to 70 per cent of the water-holding capacity. Had the loss of water by evaporation been the cause of the fluctuations observed, these soils should have undergone an increase, rather than a continued decrease, in nitrate content during the final 28 days. In fact the amounts of moisture lost were practically negligible, in view of the weight of soil employed $-4000 \mathrm{gm}$. - and of the semi-weekly additions of water.

In considering the data from the soils in the warm greenhouse it will be noticed that the fluctuations in accumulated nitrates are less evident and more irregular than for the soils kept in the main greenhouse. It will also be noticed that the time periods of fluctuation in nitrate accumulation do not coincide closely with those of the other soils. This might be expected, as there was very little correlation between the climatic factors existing in the two greenhouses. In the latter, used chiefly for the winter forcing of roses, a uniformly warm temperature was maintained. It may be observed from table 5 that in practically every case the rate of nitrification and nitrate accumulation was greater for the same materials at the same time intervals at these higher temperatures (by $3^{\circ}$ to $5^{\circ} \mathrm{C}$.), than in the main greenhouse at the lower tem- 
peratures. This clearly shows the favorable influence of increased temperatures on nitrification.

It should be observed that in no case did the temperatures attained in these studies reach the optimum temperatures of $30^{\circ}$ to $35^{\circ} \mathrm{C}$. for nitrification as reported by Jacob, Allison and Braham (45), and by Panganiban (63). The purpose of this experiment was to compare at rather low soil temperatures the rate of nitrification of the nitrogen supplied by these materials, in order to simulate, as far as possible, the temperature conditions existing in field soils of this type at the time of planting early truck crops. The soil-temperatures of the experimental field at Snow Hill, Maryland, were recorded by thermographs during the growing season of 1924 , for which the data on crop yields are included in part II of this paper.

For consecutive 14-day periods up to a total of 70 days from the date of planting early potatoes, the bi-weekly mean temperatures of the field soil at a depth of 6 inches were $5^{\circ}, 6^{\circ}, 3.5^{\circ}, 2^{\circ}$, and $1^{\circ} \mathrm{C}$. less than those recorded for corresponding periods in the main greenhouse. The other factors encountered in field conditions will be discussed in connection with the field-plot data.

Although the nitrogen from tankage nitrified slightly more rapidly than from fish at the higher temperatures, the nitrate accumulation from these two materials does not seem consistently different. Urea nitrified more rapidly than any of the other materials compared, except at the lowest temperature level, for which, however, it gave the highest nitrate accumulation after 84 days.

Sulfate of ammonia nitrified less rapidly than urea, fish, or tankage during the first 4 to 6 weeks. At the higher temperatures, however, it nitrified more rapidly than did the activated sewage sludge. Attention is called in table 3 to the high nitrate accumulation from sulfate of ammonia at the end of the 98-day period. There was a direct correlation between the nitrate accumulation from this material and the $\mathrm{H}$-ion concentration, the lowest $\mathrm{pH}$ value, 5.2, accompanying the maximum nitrate content from the sulfate of ammonia treatment. An interesting problem is suggested regarding the permanence of the nitrate accumulations from sulfate of ammonia with respect to the effect of low $\mathrm{pH}$ values on the utilization of nitrates by soil microörganisms.

In general after the first 28 days the activated sewage sludge nitrified more slowly than the other nitrogenous materials and produced a lower nitrate accumulation. At the lowest temperature level, however, it compared favorably with all of the materials employed, while at the highest temperature level it ultimately gave a nitrate accumulation comparable with that from the other materials, with the exception of sulfate of ammonia. In view of the fact that many of the favorable results reported for this material were obtained in northern states and in Canada, the data from these studies may be significant in indicating its value as an organic nitrogenous material in cold climates and in cool growing seasons. On the other hand the slow but steady response obtained at the highest temperature level would suggest a definite value for 
activated sludge under midseason conditions. Its low nitrogen content, 5.1 per cent, is unfavorable for its utilization as a source of nitrogen in fertilizer mixtures, but its excellent mechanical condition and drying properties would suggest a definite value as a conditioner and auxiliary source of nitrogen. Inasmuch as this material consists very largely of dried and reversible organic colloids, the gradual rate of nitrification may be closely related to the colloidal property of the activated sewage sludge. Further investigations with this material are being conducted under field conditions, and the colloidal phase of the problem will be studied in more detail.

The amount of nitrogen added to these soils, as in Series I, was equivalent to 57.6 p.p.m. It will be noticed in table 5 that at the lowest temperatures, and up to the end of the 98-day period only one material, urea, had produced this amount of nitrate nitrogen. In the shaded soils in the main greenhouse, urea, tankage, sulfate of ammonia, and fish in the order named had produced practically this amount in 70 days. At the highest temperature level, after 42 days the added nitrogen was equaled in amount by the nitrate nitrogen produced from all the materials compared, except activated sewage sludge.

In comparison with soil-nitrification studies as reported by Fraps (29), and others, in which the maximum amount of nitrate formation took place within the first 4 weeks, the relatively slow rates of nitrification shown by this soil during the early weeks and the high nitrate accumulations in the later periods, are worthy of notice. Not only were the temperature levels employed lower than usually has been the case in such studies, but the bacterial population of this soil is comparatively low. The low content of total organic matter, and the porous drouthy conditions observed in the field, explain this deficiency. The work of Bonazzi (13) on the mechanism of nitrification would indicate that a carbon dioxide deficiency in the early stages may possibly have retarded the rate of nitrification.

With respect to $\mathrm{H}$-ion concentration there was no observable correlation with the differences in mean temperatures. With the exception of sulfate of ammonia, which invariably decreased the $\mathrm{pH}$ values, the various materials gave only inconsistent and inconsequential differences in soil reaction.

Series III. The leaching of nitrates as influenced by various nitrogenous materials

The duration, the periods of sampling, the soil, and the analysis and rate of application of the fertilizer were the same in Series III as in Series I and II. Twelve glass percolation cylinders 7 inches in diameter by 14 inches in depth and slightly conical in shape, were used as containers. These were enclosed in a large wooden case 12 by 135 by 14 inches, as shown in figure 1.

To insure adequate drainage at the outlet and to prevent the loss of soil, 60 gm. of quartz gravel, the size of small marbles, was placed in the bottom of each cylinder and upon this was placed a layer of fine gravel. Each of the cylinders were then filled with $5500 \mathrm{gm}$. of sifted air-dry soil. The soil was moistened and leached six times between the dates of October 29 and November 
26, to insure uniform drainage conditions. The leachings of November 26 contained an average of $4.3 \mathrm{mgm}$. of nitrate nitrogen. The top 3 inches$1000 \mathrm{gm}$. - of the soil was then removed from each cylinder and air-dried, after which it was thoroughly mixed with $5.5 \mathrm{gm}$. of 7-6-5 fertilizer and returned to the percolators. The fertilizer was mixed with the surface 3 inches of soil, rather than with the entire mass, to prevent mechanical loss from washing. The soil was then moistened by the addition of $200 \mathrm{cc}$. of distilled water and at 14-day intervals thereafter, the entire mass was leached with $825 \mathrm{cc}$. of distilled water added slowly to each cylinder. The volume of leachings obtained from each is shown in table 8 . Calculated on the acre-inch basis for rainfall, and on the assumption that the weight of one acre of surface soil is 2 million pounds, these additions approximate a bi-weekly rainfall of $1 \frac{1}{2}$ inches. Three days

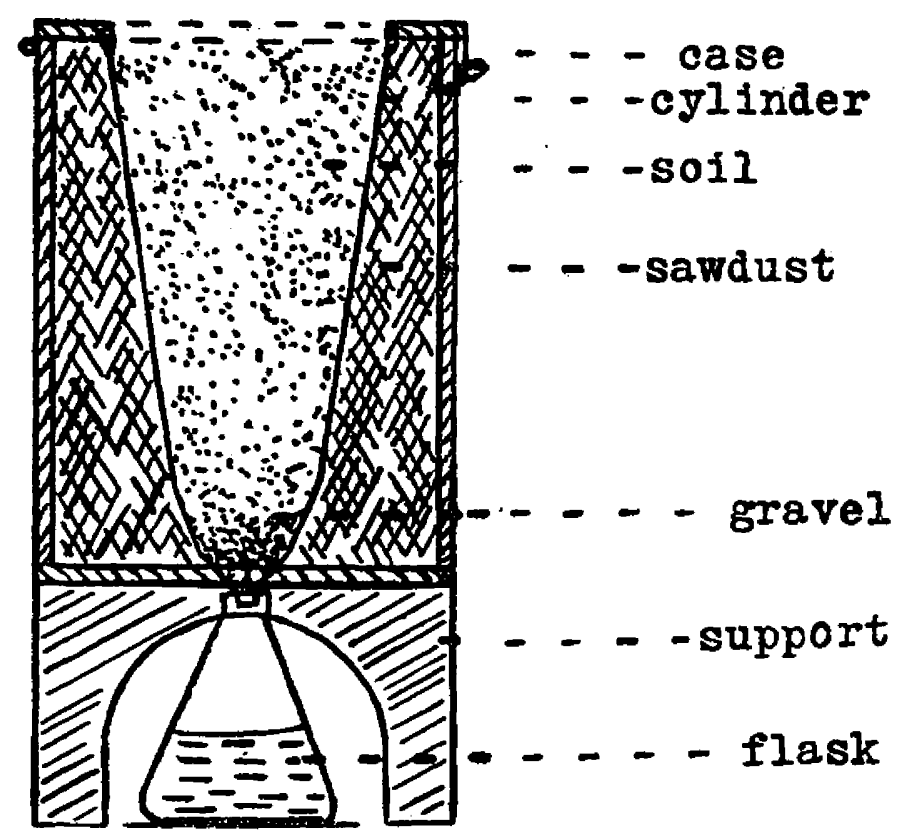

Fig. 1. Diagramatic Cross-section of Cylmnder and Case

after each addition of water the soil in each cylinder was cultivated to a depth of $\frac{1}{2}$ inch.

The application of $5.5 \mathrm{gm}$. of fertilizer to $5500 \mathrm{gm}$. of soil corresponds to a field application of 2000 pounds per acre of the fertilizer mixture, which contains the equivalent of $\mathbf{1 1 5 . 2}$ pounds of nitrogen. In each mixture all of the phosphorus was derived from 16 per cent acid phosphate and all of the potassium from potassium sulfate. Nitrate of soda, sulfate of ammonia, dried ground fish, and packing-house tankage were used singly and in combination as the sources of nitrogen. The various proportions of nitrogen carriers used for each cylinder are given in tables 6 and 7 . In the fertilizers containing all four of these nitrogenous materials, the inorganic nitrogen was supplied in equal amounts by nitrate of soda and sulfate of ammonia, and the organic 
TABLE 6

Nitrogen (as nitrate) leached at 14 day intervals with totals to date

(Nitrogen added in fertilizer $316.6 \mathrm{mgm}$.)

\begin{tabular}{|c|c|c|c|c|c|c|c|c|c|c|c|c|c|c|c|c|c|}
\hline \multirow[b]{2}{*}{ NOURER } & \multirow[b]{2}{*}{ SOURCE OF NITROGEN IN 7-6-5 PERTILIZER* } & \multicolumn{2}{|c|}{$\begin{array}{c}\text { DECEMBER } \\
14 \text { DAYS }\end{array}$} & \multicolumn{2}{|c|}{$\begin{array}{c}\text { JANUARY } 14 \\
28 \text { DAYS }\end{array}$} & \multicolumn{2}{|c|}{$\begin{array}{l}\text { JANUARY } 28 \\
42 \text { DAYS }\end{array}$} & \multicolumn{2}{|c|}{$\begin{array}{c}\text { FEBRDARY } 11 \\
56 \text { DAYS }\end{array}$} & \multicolumn{2}{|c|}{$\begin{array}{c}\text { FEBRUARY } 25 \\
70 \text { DAYS }\end{array}$} & \multicolumn{2}{|c|}{$\begin{array}{l}\text { MARCH } 11 \\
\text { 84 DAYS }\end{array}$} & \multicolumn{2}{|c|}{$\begin{array}{l}\text { MARCH } 25 \\
98 \text { DAYS }\end{array}$} & \multicolumn{2}{|c|}{$\begin{array}{l}\text { APRIL } 8 \\
\text { 112 DAYS }\end{array}$} \\
\hline & & 总 & 吾 & 营 & 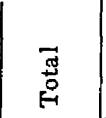 & 弟 & 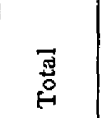 & 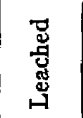 & 苞 & 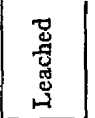 & $\underset{\mathrm{J}}{\mathrm{F}}$ & 芯 & 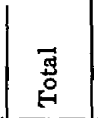 & 营 & 苨 & 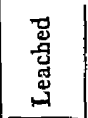 & 苞 \\
\hline & & $m g m$. & $m g m$. & mgm. & $\mathrm{mgm}$. & $m g m$. & $m \mathrm{gm}$ & mgm. & $m g m$. & $m g m$. & mgm. & $m g m$. & mgm. & $m g m$ & mgm. & $m g m$ & $m g m$ \\
\hline 1 & Nitrate of soda & 62.8 & 62.8 & 186.4 & 249.2 & 68.8 & 318.0 & 22.4 & 340.4 & 6.9 & 347.3 & 3.6 & 350.9 & 3.1 & 354.0 & 5.1 & 1359.1 \\
\hline 2 & Sulfate of ammonia & 21.5 & 21.5 & 78.5 & 100.0 & 84.9 & 184.9 & 51.2 & 236.1 & 14.9 & 251.0 & 6.4 & 257.4 & 4.5 & 261.9 & 5.6 & 267.5 \\
\hline 3 & Dried ground fish & 15.9 & 15.9 & 68.8 & 84.7 & 68.6 & 153.3 & 51.8 & 205.1 & 21.1 & 226.2 & 16.8 & 243.0 & 10.0 & 253.0 & 10.8 & 8263.8 \\
\hline 4 & Urea & 25.1 & 25.1 & 105.0 & 130.1 & 76.2 & 206.3 & 40.5 & 246.8 & 9.1 & 255.9 & 5.2 & 261.1 & 4.7 & 265.8 & 6.7 & 7272.5 \\
\hline 5 & Packing house tankage & 21.8 & 21.8 & 76.1 & 97.9 & 71.8 & 169.7 & 39.2 & 208.9 & 20.5 & 229.4 & 12.8 & 242.2 & 8.1 & 250.3 & 10.8 & 8261.1 \\
\hline 6 & $\frac{1}{2}$ nitrate; $\frac{1}{2}$ sulfate & 79.3 & 79.3 & 127.6 & 206.9 & 74.3 & 281.2 & 30.0 & 211.2 & 9.8 & 321.0 & 5.5 & 326.5 & 4.2 & 330.7 & 6.2 & 2336.9 \\
\hline 7 & $\begin{array}{l}40 \text { per cent inorganic; } 60 \text { per cent } \\
\text { organic }\end{array}$ & 45.4 & 45.4 & 87.2 & 132.6 & 74.2 & 206.8 & 41.9 & 248.7 & 16.8 & 265.5 & 10.9 & 276.4 & 8.4 & 284.8 & 9.4 & 4294.2 \\
\hline 8 & $\begin{array}{l}50 \text { per cent inorganic; } 50 \text { per cent } \\
\text { organic }\end{array}$ & 55.7 & 55.7 & 106.4 & 162.1 & 54.4 & 216.5 & 42.7 & 259.2 & 15.8 & 275.0 & 11.6 & 286.6 & 6.1 & 292.7 & 8.2 & 2300.9 \\
\hline 9 & $\begin{array}{l}60 \text { per cent inorganic; } 40 \text { per cent } \\
\text { organic }\end{array}$ & 39.4 & 39.4 & 94.5 & 133.9 & 63.5 & 197.4 & 37.9 & 235.3 & 14.8 & 250.1 & 9.1 & 259.2 & 6.0 & 265.2 & 6.8 & 8272.0 \\
\hline 10 & $\begin{array}{l}70 \text { per cent inorganic; } 30 \text { per cent } \\
\text { organic }\end{array}$ & 43.1 & 43.1 & 127.6 & 170.7 & 67.4 & 238.1 & 37.0 & 275.1 & 12.0 & 287.7 & 7.5 & 295.2 & 7.3 & 302.5 & 6.9 & 9309.4 \\
\hline 11 & $\begin{array}{l}80 \text { per cent inorganic; } 20 \text { per cent } \\
\text { organic }\end{array}$ & 30.1 & 30.1 & 171.8 & 201.9 & 72.4 & 274.3 & 42.0 & 316.3 & 9.9 & 326.2 & 5.4 & 331.6 & 4.1 & 335.7 & 5.7 & $\begin{array}{ll}741.4\end{array}$ \\
\hline 12 & Check-0-6-5 & 15.4 & 15.4 & 19.7 & 35.1 & 6.9 & 42.0 & 8.4 & 50.4 & 3.6 & 54.0 & 5.1 & 59.1 & 3.1 & 1) 62.2 & 5.3 & \begin{tabular}{l|l}
3 & 67.5
\end{tabular} \\
\hline
\end{tabular}

$* 5.5 \mathrm{gm}$. fertilizer per $5500 \mathrm{gm}$. soil. 
nitrogen, in equal amounts by fish and tankage. Except for cylinder 4, in which urea was used as the sole source of nitrogen, these mixtures and rates of application are exact duplicates of those employed in the field-plot experiments.

Table 6 gives the milligrams of nitrate nitrogen leached at each 14-day interval with the total amounts to date. Table 7 gives the same information in terms of percentage of the added nitrogen leached to date at the end of each 14-day interval. Table 8 is included merely to show the drainage conditions which existed at each date of leaching throughout the total period of 112 days.

TABLE 7

Proportion of added nitrogen leached at 14-day intervals

( $825 \mathrm{cc}$. distilled water-equivalent to 1.5 inches rainfall added every 14 th day)

\begin{tabular}{|c|c|c|c|c|c|c|c|c|c|}
\hline 草 & SOIRRCE OF NITROGEN IN $7-6-5$ FERTILIZER & 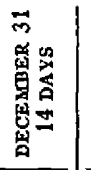 & 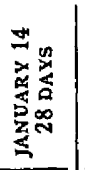 & 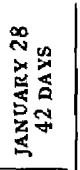 & 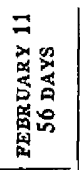 & 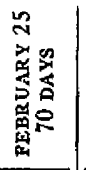 & 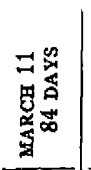 & 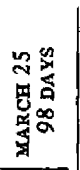 & 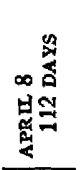 \\
\hline & & $\begin{array}{l}\text { ser } \\
\text { cent }\end{array}$ & $\begin{array}{l}\text { per } \\
\text { cent }\end{array}$ & $\begin{array}{l}\text { per } \\
\text { cent }\end{array}$ & $\begin{array}{c}\text { per } \\
\text { cent }\end{array}$ & $\begin{array}{l}\text { per } \\
\text { cent }\end{array}$ & $\begin{array}{l}\text { per } \\
\text { cent }\end{array}$ & $\begin{array}{l}\text { per } \\
\text { cent }\end{array}$ & $\begin{array}{l}\text { per } \\
\text { cent }\end{array}$ \\
\hline 1 & Nitrate of sorla & 15.0 & 67.6 & 87.2 & 91.6 & 92.6 & 92.2 & 92.2 & 92.1 \\
\hline 2 & Sulphate of ammonia & 1.9 & 20.5 & 45.1 & 58.6 & 62.2 & 62.6 & 63.1 & 63.2 \\
\hline 3 & Dried ground fish & 0.2 & 15.7 & 35.2 & 48.9 & 54.4 & 58.1 & 60.3 & 62.0 \\
\hline 4 & Urea & 3.1 & 30.0 & 51.9 & 62.0 & 63.8 & 63.8 & 64.3 & 64.8 \\
\hline 5 & Packing house tankage & 2.0 & 19.8 & 40.3 & 50.1 & 55.4 & 57.9 & 59.4 & 01.1 \\
\hline 6 & $\frac{1}{2}$ nitrate; $\frac{1}{2}$ sulfate & 20.2 & 54.3 & 75.6 & 82.4 & 84.3 & 84.5 & 84.8 & 85.1 \\
\hline 7 & $\begin{array}{l}40 \text { per cent inorganic; } 60 \text { per cent } \\
\text { organic }\end{array}$ & 9.5 & 30.8 & 52.1 & 62.6 & 66.8 & 68.6 & 70.3 & 71.6 \\
\hline 8 & $\begin{array}{l}50 \text { per cent inorganic; } 50 \text { per cent } \\
\text { organic }\end{array}$ & 12.7 & 40.1 & 55.1 & 66.1 & 69.8 & 71.8 & 72.8 & 73.7 \\
\hline 9 & $\begin{array}{l}60 \text { per cent inorganic; } 40 \text { per cent } \\
\text { organic }\end{array}$ & 7.6 & 31.2 & 49.1 & 58.4 & 61.9 & 63.2 & 64.1 & 64.6 \\
\hline 10 & $\begin{array}{l}70 \text { per cent inorganic; } 30 \text { per cent } \\
\text { organic }\end{array}$ & 8.7 & 42.8 & 61.9 & 71.0 & 73.8 & 74.6 & 75.9 & 76.4 \\
\hline 11 & $\begin{array}{l}80 \text { per cent inorganic; } 20 \text { per cent } \\
\text { organic }\end{array}$ & 4.6 & 52.7 & 73.4 & 84.0 & 86.0 & 86.1 & 86.4 & 86.5 \\
\hline 12 & \multicolumn{8}{|c|}{ Check $0-6-5$ (subtracted in each case for the corresponding period) } & \\
\hline
\end{tabular}

* $5.5 \mathrm{gm}$. fertilizer per $5500 \mathrm{gm}$. soil.

The original soil contained 0.041 per cent of total nitrogen, or $2.255 \mathrm{gm}$. in each cylinder, to which was added $0.3166 \mathrm{gm}$. in the fertilizer mixture. From table 6 it may be observed that after subtracting the amount leached from the checks, the total amount of nitrate-nitrogen recovered after 112 days was in no case equal to that added in the fertilizer. Other investigators have shown that soluble salts of phosphorus and potassium stimulate the nitrification of the nitrogen of the soil. A comparison of the $4.3 \mathrm{mgm}$. of nitratenitrogen per cylinder, obtained from the last leaching prior to the addition of the fertilizer, with the amounts shown for cylinder 12 at the 14- and 28-day 
periods, indicates a marked stimulation of nitrification by the acid phosphate and potassium sulfate. A part of this stimulation must be ascribed, however, to the thorough aëration of the portion of soil removed for mixing with the fertilizer.

It must be recognized that not all of the nitrogen leached from any one of the cylinders came from the fertilizer. In the two series just described, there were a number of instances in which the nitrate accumulation exceeded the amount of added nitrogen plus the nitrate accumulation in the soils receiving phosphate and potash only. This indicates that the nitrification of the soil nitrogen was stimulated by the nitrogenous materials as well as by the phosphorus and potassium salts. Even though the nitrate leached from any of the cylinders

TABLE 8

Total volume of leachings at various time intervals

\begin{tabular}{|c|c|c|c|c|c|c|c|c|c|}
\hline $\begin{array}{l}\text { NOM- } \\
\text { BER }\end{array}$ & TREATMENT & $\begin{array}{c}14 \\
\text { DAYS }\end{array}$ & $\begin{array}{c}28 \\
\text { DAYS }\end{array}$ & $\begin{array}{c}42 \\
\text { DAYS }\end{array}$ & $\begin{array}{c}56 \\
\text { DAYS }\end{array}$ & $\begin{array}{c}70 \\
\text { DAYS }\end{array}$ & $\begin{array}{c}84 \\
\text { DAYS }\end{array}$ & $\begin{array}{c}98 \\
\text { DAYS }\end{array}$ & $\begin{array}{l}112 \\
\text { DAYS }\end{array}$ \\
\hline & & cc. & $c c$. & $c c$. & $c c$. & $c c$. & $c c$. & $c c$. & $c c$. \\
\hline 1 & Nitrate of soda & 295 & 705 & 1,195 & 1,730 & 2,172 & 2,517 & 2,700 & 3,068 \\
\hline 2 & Sulfate of ammonia & 420 & 985 & 1,433 & 1,988 & 2,455 & $2,871 \mid$ & 3,179 & 3,574 \\
\hline 3 & Dried ground fish & 392 & 962 & 1,467 & 2,047 & 2,449 & 2,891 & 3,176 & 3,523 \\
\hline 4 & Urea & 379 & 949 & 1,324 & 1,919 & 2,329 & 2,692 & 2,970 & 3,325 \\
\hline 5 & Packing house tankage & 345 & 910 & 1,355 & $|1,892|$ & 2,327 & 2,737 & 2,997 & 3,342 \\
\hline 6 & $\frac{1}{2}$ nitrate $; \frac{1}{2}$ sulfate & 410 & 1,008 & 1,522 & 2,079 & 2,557 & 2,980 & 3,290 & 3,698 \\
\hline 7 & $\begin{array}{l}40 \text { per cent inorganic; } 60 \text { per cent } \\
\text { organic }\end{array}$ & 445 & 1,013 & 1,476 & 2,063 & $2,546 \mid$ & 2,976 & 3,299 & 3,652 \\
\hline 8 & $\begin{array}{l}50 \text { per cent inorganic; } 50 \text { per cent } \\
\text { organic }\end{array}$ & 397 & 947 & 1,352 & 1,928 & 2,332 & $2,762 \mid$ & 3,009 & 3,376 \\
\hline 9 & $\begin{array}{l}60 \text { per cent inorganic; } 40 \text { per cent } \\
\text { organic }\end{array}$ & 394 & 939 & 1,297 & $|1,762|$ & 2,126 & 2,481 & 2,729 & 3,029 \\
\hline 10 & $\begin{array}{l}70 \text { per cent inorganic; } 30 \text { per cent } \\
\text { organic }\end{array}$ & 365 & 901 & 1,273 & 1,763 & 2,143 & 2,507 & 2,783 & 3,088 \\
\hline 11 & $\begin{array}{l}80 \text { per cent inorganic; } 20 \text { per cent } \\
\text { organic }\end{array}$ & 445 & 975 & 1,337 & 1,862 & 2,262 & 2,687 & 2,989 & 3,333 \\
\hline 12 & No nitrogen & 358 & 914 & 1,292 & $|1,857|$ & $|2,222|$ & $|2,670|$ & 2,890 & 3,220 \\
\hline
\end{tabular}

receiving nitrogen did not exceed that leached from the check cylinder by the amount added, it is evident that a part of the soil nitrogen was leached and that a part of the added nitrogen was utilized by soil microörganisms. A clearer comparison of the various materials is obtained, however, by subtracting the nitrate leached from the check cylinder at each time period, from that leached from each of the other cylinders, and by expressing the net amounts as percentages of the nitrogen added in the fertilizer.

Table 7 shows in general that the rapidity of leaching and the amount of nitrates lost in the drainage water vary directly with the proportion of the nitrogen supplied by nitrate of soda. Conversely the greater the proportion of organic ammoniates, the slower was the rate of leaching and the smaller the total amounts lost during the 112-day period. From cylinders 1, 6, and 11, 
to which the nitrogen was added in the forms of nitrate of soda, of the 50-50 ratio nitrate of soda and sulfate of ammonia, and of the 80-20 ratio respectively, more than 50 per cent of the added nitrogen was leached at the first two periods, i.e. by 3 inches of rainfall. By the third period the equivalent of 50 per cent or more of the added nitrogen had been leached from the soils receiving nitrogen as urea, and as the 40-60,50-50, and 70-30 inorganic-organic ratios. By the fourth period the sulfate of ammonia, the tankage, and the 60-40 ratio had leached to the same extent. The cylinder receiving fish, however, did not lose nitrogen to this extent until the fifth period, or after 70 days had elapsed and the equivalent of a total of $7 \frac{1}{2}$ inches of rainfall had been added.

The treatments ranked as follows with respect to the total amount of nitrate leached: 1 . nitrate of soda; 2 . the $80-20$ ratio; $3 . \frac{1}{2}$ nitrate of soda- $-\frac{1}{2}$ sulfate of ammonia; 4. the $70-30$ ratio; 5 . the $50-50$ ratio; 6 . the $40-60$ ratio; 7 . urea; 8 . the $60-40$ ratio; 9 . sulfate of ammonia; 10 . fish; 11 . tankage. These may also be considered the relative rates of availability.

Cylinder 9, which received its nitrogen from the $60-40$ ratio is evidently out of line, although no satisfactory explanation has been found. It may be due in part to a greater evaporation from the surface of the soil and hence to a slightly smaller total volume of leachings, as shown in table 8 . For the first three periods, however, the volume of leachings from this cylinder was greater than from some of the others. The growth of oats, planted in these cylinders after the 112-day period, seems to indicate that an appreciable amount of the fertilizer nitrogen added to this cylinder remains in the soil. In fact, for all the cylinders the growth of this crop is inversely proportional to the amount of nitrate leached.

At the start of this experiment no analyses were made to determine the amounts of ammonia-nitrogen which may have leached from the cylinders receiving sulfate of ammonia. It is not probable that any appreciable amount of ammonia-nitrogen was leached as such. The following considerations would support this belief: (a) the fact that the soil was slightly acid, $\mathrm{pH} 6.4$; (b) the fertilizer was added to the surface 3 inches only; $(c) 14$ days elapsed between the moistening of the soil and the date of the first leaching; $(d)$ the actual amount and the proportion of nitrate leached at the first period from the cylinder receiving nitrate of soda were relatively small. The fact that nitrates leach much more rapidly than ammonia, especially in acid soils, has long been recognized. Fraps (28) has shown that $500-\mathrm{gm}$. portions of soil, to which ammonium chloride had been added to the extent of 51.7 p.p.m. of ammonia nitrogen, when leached immediately, retained from 61 to 98.5 per cent of the ammonia added. For cylinder 2, to which all of the nitrogen added was in the form of sulfate of ammonia, the $316.6 \mathrm{mgm}$. of nitrogen added to $5500 \mathrm{gm}$. of soil is equivalent to $\mathbf{5 7 . 5}$ p.p.m. of ammonia nitrogen. In view of the aforestated considerations and conditions of this experiment, it is improbable that any appreciable amount of nitrogen was lost in the leachings in the ammonia form. 
Considering from another angle, this question for cylinder 2 , the $5.5 \mathrm{gm}$. of fertilizer added contained $1.493 \mathrm{gm}$. sulfate of ammonia. Adding the approximate $1200 \mathrm{cc}$. of capillary moisture held by the soil in each cylinder, to the $825 \mathrm{cc}$. of water used to leach the soil, gives a total of approximately 2 liters of water present at each leaching. These amounts of water and sulfate of ammonia would give approximately a $\frac{1}{1} N$ solution. Wolkoff (82) found that on adding $4 \mathrm{cc}$. of a $\frac{1}{32} N$ ammonium sulfate solution to $20 \mathrm{gm}$. of Sassafras medium sandy loam, the freezing point depression was lowered 47 per cent because of absorption. Garretson (32) in studying the soils of Java, added sulfate of ammonia in amounts equal to 1 per cent of the weight of the soil. He found that after nitrification, about 81.5 per cent of the added nitrogen could be leached as nitrate; whereas before nitrification, from one to two per cent only of the added nitrogen was leached by the same procedure. From the foregoing it seems permissible to assume that the leaching of nitrogen in the form of ammonia did not appreciably influence the total loss of nitrogen in the drainage water.

The rapid leaching of nitrates during the early periods from cylinder 4, in which urea was used entirely as the source of nitrogen, is in complete agreement with the pot experiments of Series I and II. The relatively small total amount of nitrate leached from this cylinder during the entire period, is also in agreement with the data of the preceding experiments, in that the total nitrate accumulation from this material was in many instances less than from sulfate of ammonia, fish, or tankage.

There are several factors which influence the leaching of nitrogen applied to soils in commercial fertilizers. Briefly, they are: the chemical form in which the nitrogen is applied, the organic matter and nitrogen content of the soil, the microbiological flora, the mechanical composition, the moisture content, and the soil temperature, all of which influence the rate of nitrate formation. The influence of these factors was demonstrated in the pot cultures of Series I and II. In this Series the influence of various combinations of nitrogenous materials on the rate of nitrification is apparent. Since all useful nitrogenous fertilizer materials produce appreciable amounts of nitrate nitrogen in the soil within the growing season in which the application is made, the question resolves itself to that of a balance between the rate of nitrification and the soil and climatic factors which favor or inhibit rapid leaching. The combinations of nitrogenous materials employed in this experiment indicate that within certain limits the rate of nitrate formation may be controlled by the judicious mixing of various materials.

It is well known that, because of climatic and soil temperature conditions, early vegetable crops can best be produced on sandy soils. Such soils are always relatively deficient in clay and silt, i.e. in colloids and the materials from which colloids may readily be formed. Although the soil selected for these leaching experiments may present a rather extreme type of these soils, in that it contains nearly 89 per cent total sands and only 11 per cent silt and 
clay, it affords an excellent medium for the comparison of nitrogenous materials. Furthermore, considerable areas of this soil exist, and may be cropped successfully when the sources of nitrogen are adequatey balanced, and the method and time of application are adapted to the existing conditions.

There is a definite and well defined nitrogen problem with these soils. Their mechanical composition, the summer drouth, and the cropping system to which they are best adapted, all make it impractical to attempt to build up high organic matter and total nitrogen contents. The cash crops require appreciable quantities of nitrate nitrogen early in the season, in order to force growth against the influence of unfavorable soil and air temperatures. At such times the soil temperature is usually too low to promote rapid nitrification of many of the commercial organic materials used in fertilizers. Consequently some nitrate nitrogen must be included. Small local areas in the Sassafras soils and extensive areas of the Norfolk soils, have subsoils containing even less silt and clay than the surface soil. The present experiment has shown that soils deficient in colloidal material have a relatively small capacity for the absorption of nitrates.

At the experimental field at Snow Hill, Maryland, there was a total rainfall of 18.2 inches during the growing season for the early potato crop, from March 26 to June 30, 1924. In addition, the date of planting had been considerably delayed by excessive rainfall prior to March 26. Both on May 24 and June 9, more than 3 inches of rain was measured by the rain-gauge within 24-hour periods. On May 18 nearly 2 inches of rain fell, and on March 29, April 6, and May 21, 1 inch or more of rainfall was recorded. These heavy precipitations undoubtedly leach a considerable proportion of the nitrate nitrogen present at the time from the surface soil to the subsoil. Unless the subsoil has an appreciably higher silt and clay content than the surface soil and if its capillary contact is broken by a layer of relatively coarse sand, it is doubtful whether much of the nitrate-nitrogen leached is again brought to the surface. Especially in these tidewater regions, lying from 5 to 20 feet above mean sea level, and in which the pemanent water table is found at a depth of 2 to 4 feet, the recovery of nitrates once leached from the surface soil is evidently quite small.

The duration of the leaching experiments was 112 days, during which time the equivalent of 12 inches of rainfall had been added to each cylinder. In the field during the 1924 season, this amount of precipitation had occurred within 62 days after the early potato crop had been planted. Table 7 shows that, from cylinders 1,6 , and 11 , which received 100,50 , and 40 per cent respectively of the added nitrogen as nitrate of soda, the equivalent of 92 to 85 per cent of the fertilizer nitrogen had been leached. In fact 6 inches, or one-half the amount of rainfall, in 6 days less time, leached $91.6,82.4$, and 84.0 per cent respectively of the amount of nitrogen added to these cylinders. From this it is evident that for these soils when the amount of nitrate present is in excess of the feeding-power of the crop plus the absorptive capacity of 'the soil, the 
amount of nitrate leached depends entirely on the characteristics of the subsoil and the distribution and amount of rainfall. The malnutrition of the early potato crop, so frequently observed on these soils, may thus be explained by the fact that too great a portion of the fertilizer nitrogen was supplied as nitrates or readily nitrifiable materials.

Aside from the growing of leguminous green manure crops whenever practicable, the nitrogen problem for these soils resolves itself into that of using a fertilizer that will yield sufficient nitrate nitrogen to produce the early growth desired, but which at no time will give a large accumulation of nitrate to be lost in the drainage water. To obtain this result all of the type materials compared in these experiments can be employed profitably, but the first essential is a clear understanding of the soil conditions influencing the rate at which each material produces nitrate nitrogen.

\section{SUMMARY AND CONCLUSIONS}

1. The optimum soil-moisture content for nitrate production from various nitrogenous materials applied in a 7-6-5 complete fertilizer, was found between 50 and 60 per cent of the water-holding capacity for Norfolk sandy loam soil.

2. There was a larger nitrate accumulation from urea at 70 per cent of the water-holding capacity of the soil than from sulfate of ammonia, dried ground fish, or packing house tankage.

3. After the first period of rapid nitrification, the fluctuations of nitrate nitrogen in this soil appear to be the result of the activity of soil microörganisms, rather than of differences in soil-moisture, temperature, or reaction.

4. Up to 20 to $30^{\circ} \mathrm{C}$, which was the highest temperature range employed, nitrate production from sulfate of ammonia, urea, dried ground fish, packing-house tankage, and activated sewage-sludge increased directly with the temperature.

5. At all temperatures, urea showed the most rapid rate of nitrification; at all except the lowest temperature level, sulfate of ammonia gave the highest ultimate accumulation of nitrate.

6. When both rate of nitrate production and rate of nitrate accumulation in this soil are considered, the materials employed rank in the following order: nitrate of soda, urea, sulfate of ammonia, dried ground fish, packing-house tankage, and activated sewage sludge.

7. The leaching of nitrates from Norfolk sandy loam soil, following an application of a 7-6-5 fertilizer equivalent to 2000 pounds per acre, varied directly with the proportion of the nitrogen supplied by nitrate of soda in the mixture.

8. When used as the sole source of nitrogen in this analysis ratio, there was little difference in the total amounts of nitrates leached from sulfate of ammonia, urea, dried ground fish or packing-house tankage; although more nitrate-nitrogen leached during the early periods from the cylinder receiving nitrogen from urea.

\section{REFERENCES}

(1) Albrecht, W. A. 1919 Nitrate production in soil as affected by the crop and cultivation. Missouri Agr. Exp. Sla. Bul. 163: 67-68.

(2) Albrecht, W. A. 1922 Nitrate accumulation under straw mulch. Soil Sci. 14: 299-305.

(3) Albrecht, W. A. 1924 Soil studies at the Missouri Station. Missouri Agr. Exp. Sta. Bul. 210.

(4) Allison, F. E., Braham, J. M., and McMurtey, J. E., JR. 1924 Field experiments with atmospheric nitrogen fertilizer. $U$. S. Dept. Agr. Bul. 1180. 
(5) Alusson, F. E., Vinex, E. B., Skinner, J. J., AND REID, F. R. 1924 Greenhouse experiments with atmospheric nitrogen fertilizers and related compounds. Jour. Agr. Res. 28: 971-976.

(6) Appleman, C. O. 1918 Physiological basis for the preparation of potatoes for seed. Md. Agr. Exp. Sta. Bul. 212.

(7) Barthex, C. 1920 Nitrate formation in soil. Svensk Kem. Tidskr. 32: 173-183. (Abs. in Chem. Abs. 15: 1053. 1921.)

(8) BARTher, C., AND Bengston, N. 1920 The nitrification of stable manure nitrogen in soil. Meddel. Centralanst. Försöksv. Jordbruksomradet (Sweden) 211: 18. (Abs. in Exp. Sta. Rec. 45: 423.)

(9) Brzzell, J. A. 1922 Disappearance of nitrates in soil under timothy. Jour. Amer. Soc. Agron. 14: 320-326.

(10) BLAIR, A. W. 1922 Agricultural and commercial values of nitrogenous plant foods. Jour. Amer. Soc, Agron. 14: 162-167.

(11) BLAIR, A. W., ANd Prnvce, A. L. 1922 Variation of nitrate nitrogen and pH values of soils from the nitrogen availability plots. Soil Sci. 14: 1-19.

(12) Blair, A. W., AND PRince, A. L. 1924 Influence of varying ratios and phosphoric acid and potash on crop yield and nitrogen recovery. Soil Sci. 17: 327-331.

(13) Bonazzi, A. 1921 On nitrification. IV. The carbon and nitrogen relations of the nitrite ferment. Jour. Bact. 6: 479-499.

(14) Bonazzi, A. 1923 On nitrification. V. The mechanism of ammonia oxidation. Jour. Bact. 8: 343-363.

(15) Briggs, L. J., ET AL. 1904 The Centrifugal Method of Soil Analysis. U. S. Dept. Agr. Bur. Soils Bul. 24.

(16) Brenchley, W. E., AND Richards, E. H. 1920 The fertilizing value of sewage sludge. Jour. Soc. Chem. Indus. 39: $177 \mathrm{~T}-181 \mathrm{~T}$.

(17) Brows, H. D. 1920 Report on the fertilizer value of activated sludge. Ontario Bd. - Heallh Ann. Rpt. 39: 130-155.

(18) Broy P. E., AND Gowda, R. N. 1924 The effect of certain fertilizers on nitrification. Jour. Amer. Soc. Agron. 16: 137-146.

(19) Carpenter, P. H., ANd Bose, A. K. 1921 Ammonia, nitrate and carbon dioxide formation in relation to the best mechanical soil condition. Indian Tea Assoc., Sci. Dept. Quart. Joutr. 3: 103-120.

(20) Cemardon Palactos, C. E. 1921 Preliminary studies on ammonification and nitrifcation in Puerto Rico soils. Rev. Agr. Peurto Rico 5: p. 37-46. (Abs. in Exp. Sta. Rec. 44: 814.)

(21) Chevalier, C. 1923 Utilization of synthetic urea as a nitrogenous fertilizer. Prog. Agr. et Vitic. (Ed.l'Est-Centre) 44: 257-260. (Abs. in Exp. Sta. Rec. 50: 424.)

(22) CIARKE, G. R. 1924 Soil acidity and its relation to the production of nitrate and ammonia in woodland soil. Oxford Forestry Mem. 2: 27.

(23) Colewan, D. A. 1917 The influence of sodium nitrate upon nitrogen transformations in soils with special reference to its availability and that of other nitrogenous manures. Soil Sci. 4: 345-432.

(24) Coleman, L. C. 1907 Researches on nitrification. Cent. Bakt. 2: 401, 484.

(25) Denison, I. A. 1922 The nature of certain aluminum salts in the soil and their influence on ammonification and nitrification. Soil Sci. 13: 81-106.

(26) Eerengerc, F., AND Sceutrte, K. 1916 Contributions to the explanation of the manganese question. Jour. Landw. 64: 37-129.

(27) Erdman, L. W. 1923 The effect of gypsum on Iowa soils. Soil Sci. 15: 137-155.

(28) Fraps, G. S. 1920 Nitrification in Texas Soils. Texas Agr. Exp. Sta. Bull. 259.

(29) Fraps, G. S. 1921 Relation of soil nitrogen, nitrification and ammonification to pot experiments. Texas Agr. Exp. Sta. Bul. 283. 
(30) Fred, E. B., AND Graux, E. J. 1916 Some factors that influence nitrate formation in acid soil. Soil Sci. I: 317-338.

(31) Garder, T., AND Hagum, O. 1919 Studies on nitrification and H-ion concentration. Bergens Mus. Aarbok. Naturv. Raekke, 1919-20: (1), 1-31. (Abs. in Exp. Sta. Rec. 50: 722.)

(32) Garretson, F. C. 1921 An investigation on nitrification and denitrification in tropical soils. Arch. Suikerindus. Nederland. Indië 29: 1397-1460; 1461-1530 (Abs. in Exp. Sta. Rec. 47: 214.)

(33) Geilman, W. 1922 The washing out of ammonia and nitrate nitrogen from sand soils. Jour. Landw. 70: 259-266.

(34) Gowda, R. N. 1924 Oxidation of ammonia and nitrites by micro-organisms under different conditions. Soil Sci, 17: 57-64.

(35) Gowda, R. N. 1924 Nitrates and nitrification in field soils. Soil Sci. 17: 333-342.

(36) Greaves, J. E. 1922 Influence of salts on soil bacteria. Bot. Gaz. 73: 161-180.

(37) Greaves, J. E., AND Carter, E. G. 1925. Influence of moisture on the bacterial activities in the soil. Soil Sci. 19: 361-387.

(38) Hall, Thomas D. 1923 Nitrification in some South African soils. Soil Sci. 18: 219 235.

(39) Harper, Horace J. 1924 The accurate determination of nitrates in soils-phenoldi-sulfonic acid method. Jour. Induts. Engin. Chem. 16: 180-183.

(40) Harris, F. S., AND BUTt, N. I. 1917 Effect of irrigation water and manure on the nitrates and total soluble salts of the soil. Jour. Agr. Res. 8: 333-359.

(41) Harrison, W. H. 1923 The movement of nitrates in soil and subsoil. Agr. Res. Inst., Pusa, Sci. Rpts, 1922-23: 29-31.

(42) HASElHoFf, E. 1922 Experiments with Rehmsdorf organic nitrogenous fertilizer. Ztschr. Pfanzenernähr. u. Düngung. 1. Wirtschaft-Praft.: 510-519. (Abs. in Exp. Sta. Rec. 50: 623.)

(43) HaSselHoff, E., LIEHR, O., AND FiuHRER, K. 1922 Experiments with nitrogenous fertilizer. Landw. Vers. Sta. 100: 35-58.

(43a) Hilgard, E. W. 1912 Soils. New York.

(44) Hutchinson, C. M. 1922 Soil studies at the Pusa Research Institute. Agr. Res. Inst., Pusa, Sci. Rpts. 1921-22: 41-42.

(45) Jacob, K. D., Allison, F. E., and Braham, J. M. 1924 Chemical and biological. studies with cyanamid and some of its transformation products. Jour. Agr. Res. 28: 27-69.

(46) Jounson, T. C. 1923 Four years results with potatoes at the Virginia Truck Ex periment Station. Armour \& Co. Farmers Almanac 1923.

(47) KadisH, V. H. 1924 Activated sludge, its manufacture and fertilizing value. Amer. Fert. 60: 78-91.

(48) KuYper, J. 1923 The nitrogenous fertilizers ammonium sulphate, nitrate, and urea. Arch. Suikerindus. Nederland. Indië 31: 21-25. (Abs. in Exp. Sta. Rec. 49: 20.)

(49) LemmermanN, O., AND EckL, K. 1923 Investigation on the action of ammonivm bicarbonate in comparison with ammonium sulphate and sodium nitrate in, different methods of application. Ztschr. Pflanzenernähr. u. Düngung. 2. Wirkschaft-Prakt.: 98-109. (Abs. in Exp. Sta. Rec. 51: 120.)

(50) Lemmerman, O., AND Wichers, L. 1920 The periodic influence of the time of year on the process of nitrification. Centbl. Bakt. (II) 50: 33-43.

(51) LIPMAN, C. B., AND Burgess, P. S. 1916 Ammonifiability versus nitrifiability as a test for the relative availability of nitrogenous fertilizers. Soil Sci. 3: 63-75.

(52) LIPMAN, J. G., AND BLAIR, A. W. 1918 Twenty years work on the availability of nitrogen in nitrate of soda, ammonium sulfate, dried blood and farm manures. Soil Sci. 5: 1-9. 
(53) LIPMAN, J. G., AND BLAIR, A. W. 1918 The value of nitrate of soda in crop production. N. J. Agr. Exp. Sta. Bul. 323.

(54) Litrauge, F. 1924 Decomposition of urea in soil, Ztschr. Pflansenernähr. u. Ditngung. Wiss.: 165-179. (Abs. in Exp. Sta. Rec. 51: 818.)

(55) LoHNrs, F. 1923 Influence of time of year on nitrate formation in soil. Centlb. Bakt. (II) 58: 207-211.

(56) Martin, William H. 1923 Feed balanced fertilizer ration for best potato yield returns. N. J. Agr. 4: (12): 6.

(57) Mrex, C. S., AND LIPMAn, C. B 1922 The relation of the reaction and of salt content of the medium on nitrifying bacteria. Jour. Gen. Phys. 5: 195-204.

(58) Mryake, K., AND Soma, S. 1922 Further studies on the nature of nitrification. Jour. Biochem. 1: 123-127.

(59) MUNTER, F. 1920 Investigations on chemical and bacteriological transformation in soil. Landw. Jahrb. 55: 62-138.

(60) MUNTER, F. 1923 The action of physiologically acid and alkaline nitrogen salts. Zischr. Pflansenernähr. u. Dïngung 2: Wirtschaft-Prakt.: 497-516. (Abs. in Exp. Sta. Rec, 51: 121.)

(61) MURPHY, H. F. 1924 Nitrification experiments on soils of the red prairies. Jour. Amer. Soc. Agron. 16: 130-130.

(62) Nebraska Agricultural Experiment Station 1923 Soil fertility studies at the Nebraska Station. Ann. Rpt. 1923.

(63) Panganiban, Ellas H. 1925 Temperature as a factor in nitrogen changes in the soil. Jour. Amer. Soc. Agron. 17: 1-31.

(64) Prescott, J. A. 1923 The volatilization of the ammonia of ammonium sulphate and soil reaction. Bul. Union Agr. Egypte 151: 121-128.

(65) Robrsson, C. S., Winter, O. B., AND MrlLer, E. G. 1921 Studies on the availability of organic nitrogenous compounds. Joutr. Indus. Engin. Chem. 13: 933-936.

(66) SACHS, W. H., AND AUSTIN, R. H. 1922 The effect of cultivation during the growing season on moisture content and formation of nitrates in the soil. Ark. Agr. Exp. Sta. Bul. 181: 41-42.

(67) Schermarerhors, Lysan G. 1924 Potash can change shape of sweet potatoes. $N$. J. Agr. 6: (4) 6-7.

(68) Schenemenind, W., Meyer, D., and Munter, F. 1920. Nitrogen experiments. Landw. Jahtrb. 55: 1-20.

(69) SHEDD, O. M. 1919 Effect of oxidation of sulphur in soils on the solubility of rock phosphate and on nitrification. Jour. Agr. Res. 18: 329-345.

(70) Schosbrusw, B. 1922 Progress of nitrification with time, with special reference to the periodic influence of time of year. Centbl. Bakt. (II) 56: 545-565.

(71) Surrt, R. S. 1920 Some effects of potassium salts on soils. N. Y. (Cornell) Agr. Exp. Sla. Mem. 35: 571-605.

(72) Starkey, R. L. 1924 Some observations on the decomposition of organic matter in soils. Soil Sci. 17: 293-314.

(73) Stevenson, R. E. 1920 Nitrification in acid soils. Iowa Agr. Exp. Sla. Res. Bul. 58: 331-349.

(74) Truffatt, G., and Bezssonofr, N. 1924 The most favorable form of nitrogen for major crops. Compt. Rend. Acad. Sci. 178: 723-25.

(75) Trupraut, G., and Bezssonofr, N. 1924 On the form of nitrogen most favorable to higher plants. Sci. Sol. (Truffant) 3: 1-19.

(76) United States Department of Agriculture Year Book 1921 Cost data for farm products, p. 824.

(77) Van Keniernum, W. 1922 Fertilizer Experiments with different new nitrogenous fertilizers. Mitt. Deut. Landw. Gesell. 37: 654-655. 
(78) Waksman, S. A. 1923 Influence of nitrogen fertilization upon microbiological activities of the soil. N.J. Agr. Exp. Sta. Ann. Rpt. 1922: 359-361.

(79) Waksman, S. A. 1923 Microbiological analysis of soils as an index for soil fertility: V. Methods for the study of nitrification. Soil Sci. 15: 241-260.

(80) Whitrng, A. L., AND Schoonover, W. R. 1920 Nitrate production in field soils in Illinois. Ill. Agr. Exp. Sta. Bul. 225: 21-63.

(81) Wruson, B. D. 1923 The effect of plants on the concentration of drainage water from the Cornell lysimeters. Soil Sci. 16: 427-432.

(82) Wolkofr, M. I. 1917 Adsorption of ammonium sulfate by soils and quartz sand. Soil Sci. 3: 561-564.

(83) Woods, Chas. D. 1918 Potatoes grown on Aroostook farm on fertilizers containing ammonia (nitrogen) in different forms. M. Agr. Exp. Sta. Bul. 269: 37-39. 